\begin{abstract}
Апстракт: У раду се говори о стваралаштву и иманентним поетичким назорима савременог ирачког прозаисте Хасана Бласима, чији је извор инспирације новија историја Ирака и ужас прогнаних, обесправљених и обезглављених ирачких грађана. Бласим врши ексхумацију ирачког бића, аутопсију тела и биопсију душе, сакупља њихове распарчане животе и сахрањује их у свету фикције. То чини приповедачки вешто, стилски разнолико, од надреалистичког контемплирања до кошмарног реализма, склон недозвољеним прекорачењима у изразу и теми, противно канонској арапској књижевности. Уз анализу Бласимовог света фикције, у раду је присутно указивање и на метафикцијске нити које прожимају велики број његових дела или су у њиховом фокусу, особито у погледу стваралачког порива и смисла обликовања како арапске поезије и прозе, тако и књижевности уопште. Дати поетички стубови Хасана Бласима обрађени су кроз неколико поднаслова, који представљају оријентир у развоју књижевног пута самог писца, у понечему сродног с осталим прозаистима из Ирака, с којима учествује у обликовању препознатљиве савремене ирачке књижевности.
\end{abstract}

Кључне речи: модерна ирачка књижевност, савремена ирачка проза, Хасан Бласим, метафикција, фикција, кошмарни реализам

\title{
1. Модерна ирачка књижевност
}

Процес развоја модерне књижевности у Ираку, као и већине националних арапских књижевности, обухватио је неколико деценија пре и неколико после средине XX века, очевидно се заокруживши седамдесетих година. Њени йионири, почевши од друге деценије XX века, поставили су темеље модерности, понајвише кроз подражавање, или старе арапске књижевности, или других арапских писаца, махом из Египта и Либана. Таква оријентација подразумевала је стваралаштво у дидактичком и моралистичком маниру без амбиција да књижевност забави и опчини искреним садржајем или иновативном формом.

Због неивентивности књижевних пионира, прва асоцијација на иницијаторе нове прозне и поетске поетике у Ираку повезана је с књижевницима среgюе їенерације. Тако се Фуаду ал-Текерлију (Fu’ād al-Tikarlī, 1927-2008) приписује уобличавање модерне кратке приче у Ираку, а Гаибу Туми Фарману (Ġā'ib Ṭu'ma Farmān, 1927-1990) пионирско место у писању „правог” уметничког романа. На пла- 
ну поезије, средња генерација песника, посебно Назик ал-Малаика (Nāzik al-Malā'ika, 1923-2007) и Бадр Шакир ал-Сајаб (Badr Šākir alSayyāb, 1926-1964), из корена је променила поетику арапске поезије увођењем слободног стиха, што је прекретница у девалоризацији класичне арапске касиgе - канонске моноримне песме с утврђеним метричким системом и тематским клишеима. 1 Поменути песници и прозаисти застају над питањима маргинализованог и потлаченог човека, над његовом несрећом и бедом, и остављају сведочанство о социјалној неправди у реалистичном тону, не либећи се да у редовима својих дела изусте изразе и реченице на ирачком дијалекту. У том смеру наставили су и „блистави приповедач” Абдусетар Насир ('Abd al-Sattār Nāṣir, 1947-2007)² и плејада других, млађих писаца из средње генерације, све више се служећи модернистичким књижевним поступцима у обради надолазећих, бруталних садржаја, безнадежно „надахнути“ немилосрдним политичким устројством своје земље, нетолерантним према отвореној критици.

Последње деценије ХХ века сведоче о разумљивој књижевној стагнацији, имајући у виду да се, због непрекидних деструктивних ратних „пројеката” (ирачко-ирански рат 1980-1989. и Заливски рат 1990-1991) и диктаторског режима Баас партије (1968-2003), ирачки писац није осећао ни безбедно ни подстакнуто да се посвети свом занимању. Значајан преокрет наступио је у новом миленијуму, захваљујући савременим писцима, који су претходни биланс догађаја проширили књижевним процесуирањем постсадамовске етапе. Ова етапа подразумева сагледавање последица прелаза из тоталитарног

1 Иако посвећивање прегледу укупног развоја модерне ирачке књижевности није било у фокусу домаћих арабиста, неколико извора, махом поговора у преведеним збиркама прича, даје увид у развој кратке приче у Ираку (Танасковић 1980; Лештарић 2004, 2015, 2016 итд.). На страним језицима доступан је већи број прилога разумевању развоја модерне ирачке прозе, како уже усмерених истраживања, тако и као делови историјских прегледа развоја модерне арапске књижевности. У новије време, таквих је извора све више, а као пример се може навести књига The Oxford Handbook of Arab Novelist Traditions, у којој је 13. поглавље посвећено развоју ирачке прозе, од њених пионира до значајних представника постсадамовске етапе, уз библиографске податке важних извора за проучавање развоја модерне ирачке прозе (Bahoora 2017). Што се тиче модерне ирачке поезије, арапски и страни истраживачи су јој у другој половини $\mathrm{XX}$ века били посвећенији у истицању улоге ирачких песника у увођењу и устаљивању слободног стиха. Стога дата песничка „револуција” представља незаобилазну тему у општим прегледима развоја модерне арапске књижевности (нпр. Камера д’Афлито 2012: 145-152), затим у монографијама специјализованим за модерну арапску поезију (нпр. al-Ğayyūsī 2007: 597-606), или пак само за ирачку (нпр. 'Alwān 1975).

2 Како наводи С. Лештарић у свом поговору приређене и преведене збирке прича А. Насира Најсрећнији човек на свети (Лештарић 2004), надимак „блистави приповедач“ наденуо му је 1979. године Садам Хусеин лично, усред трочасовног збора писаца, на којем је Насир иступио и искрено саопштио проблеме с којима се ирачки писци суочавају (цензура, материјални и правни статус писаца итд.). Наизглед „поткупљени“ слободоумни писац, који је тек коју годину пре провео десет месеци у самици због једне своје приче уперене против режима, ипак се није препуштао интелектуалном конформизму, изузев у неколицини случајева у којима је морао да бира између живота и смрти. 
режима - једног предвидљивог репресивног механизма, у фазу непредвидљиве деструкције, најпре окупацијом, то јест уласком америчких трупа 9. априла 2003. у Ирак, која је затим подстакла нови начин „окупације у окупацији“ од стране екстремистичких група. Ова фаза кулминирала је 2014. године оснивањем Исламске државе на територији Сирије и Ирака.

Имајући у виду наведене историјске околности, очекивано је да у првом плану савремене ирачке књижевности налазимо различите перспективе о узроцима и последицама девастације једне нације и њене земље. Посттрауматска искуства и горка сећања, исприповедана у духу постмодерне поетике, одлике су књижевног сензибилитета великог броја ирачких прозаиста, чија су дела данас доступна на многим језицима. Ови писци, на свој особени начин и усредсређујући се на један аспект деструкције и репресије, осликавају насиље над колективом, у чему су појединачни случајеви само илустрација начина на које се оно спроводи.

Заслуга за афирмацију савремене ирачке прозе припада, између осталих, Хасану Бласиму (Hasan Balāsim), кога је Јасин-Касаб још 2010. године препознао као „можда најбољег живог арапског писца“ (Yassin-Kassab 2010).

\section{2. Хасан Бласим: књижевна остварења}

Хасан Бласим је рођен у Багдаду 1973. године, као једно од деветоро деце у шиитској породици. Мајка му је била неписмена и трпељива, а отац војно лице, насилног карактера - породични профил који је утиснут у Бласимов прозни и поетски израз.

У жељи да постане писац, студирао је филмску режију на Академији филмских уметности у Багдаду јер су му саветовали да је управо такво опредељење значајно за бављење књижевношћу. Током студија снимао је кратке филмове, а упркос труду да се не дотиче директно теме диктатуре, постао је мета режимске полиције. Због тога 1998. одлази у курдистански град Сулејманију (на северу Ирака), где је снимио филм Рањена камера на курдском језику, под псеудонимом Оузада Осман, страхујући за живот чланова своје породице.

Бласим је из Сулејманије мигрирао на Запад копненим путем, без легалних исправа. Његова четворогодишња мигрантска одисеја је пут на коме је доградио преживљене године рата и диктатуре, препуштен лутрији спасења из обруча страха и насиља. У Хелсинки је коначно доспео 2004. године. Настављајући да снима документарне и уметничке филмове, све више се усредсређуе на писану реч. Писао је чланке на тему кинематографије, поетичке саставе који припадају метафикцијској књижевности, кратке приче и експресионистичку поезију. Аутор је једног романа. 
Промоција Бласимових књижевних остварења није заслуга арапских издавача и часописа. Штавише, они су му затварали врата или их условно отварали након цензуре делова који су за самог писца били најважнији. Стога се окренуо објављивању на интернету, што се у случају збирке прича Mağnūn Sāhat al-ḥurriyya (Лygaк ca Tріа слобоge, 2009) испоставило као пун погодак, мада тек након што ју је Џонатан Рајт (Jonathan Wright) превео на енглески језик. На основу енглеске верзије ове збрике, Madman of Freedom Square (2010), Бласим брзо постаје славан у западним земљама, а његова збирка уврштава се у шири избор за неколико угледних награда (Frank O'Connor Short Story Award 2010, The Independent Foreign Fiction Prize 2010, Writers in Translation 2012). Штампано, премда цензурисано издање поменуте збирке појавило се 2012. године у Бејруту и на арапском језику.

Успех прве књиге утврдила је друга збирка прича, The Iraqi Christ (Ирачки Христиос, 2013), такође у преводу Џ. Рајта, након чега је уследило превођење Бласимових остварења на друге светске језике. ${ }^{3} \mathrm{He-}$ сумњиво је за њену приступачност на више од двадесет језика, поред неспорног квалитета, заслужна награда The Independent Foreign Fiction Prize, која је Бласиму додељена 2014. године. На арапском се ова збирка прича још увек није самостално појавила већ заједно с претходном, под насловом Márad al-ǧ itat (Изложба лешева, 2015), премда такође премијерно издата на енглеском језику 2014. године, под насловом The Corpse Exibition and Other Stories of Iraq (London: Penguin Books, 2014).

Две поменуте збирке прича нису прво отискивање Хасана Бласима у књижевни свет, иако су за ширу публику доступније и прве које су га учиниле популарним, а убрзо и светиским писцем. Бласим је објављивао и друге приче, песме и есеје на интернету, али веома ретко у папирном издању. ${ }^{4}$ Текстове различите природе које је писао, махом до 2009. године, касније је сакупио у две књиге разноврсног садржаја. Једна група текстова обједињена је под називом Tifl

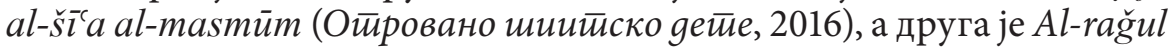
al-qāmūs (Човек-речник, 2019), уз напомену да је потоња Бласимово последње објављено дело, али и прво које је издато и у родном Багда-

3 Обе збирке прича појавиле су се у преводу на српски језик заслугом Српка Лештарића, 2015. године Луgак са Трїа слобоgе и 2016. Ирачки Христиос. Потоња је издата и у Загребу исте године, с тим што је превод начињен с енглеског језика захваљујући Михаели Велини, која је иницијалном садржају збирке додала и приче из претходне, прве збирке, због чега је наслов ове књиге проширен на Ирачки Кристи и gруїе йриче.

4 Такав изузетак је прича о Багдаду, објављена у антологији прича Madinah: City Stories from the Middle East (2008). Збирку је приредила либанска књижевница Џумана Хадад (Ğumāna Ḥaddād), окупивши различите ауторе из региона, да кроз причу о свом граду осликају његове урбане промене и портрет његових становника. Осам година касније и сам Бласим приредио је антологију прича на енглеском језику, насловљену Iraq + 100 - Stories from a century after the invasion (2016). 
ду. Ови поетични и у погледу форме и жанровске припадности неодређени текстови не представљају нарочито атрактивни део Бласимовог књижевног опуса, осим за проучаваоце књижевности уопште или, посебно, за проучаваоце његовог књижевног развоја.

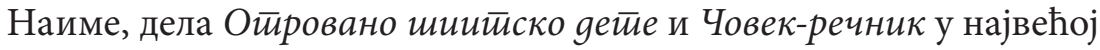
мери чине приповедни и песнички састави, неретко сирови по стилу и наглашено афективни, збркани и натопљени магловитим асоцијацијама. Може се рећи да је посреди поетична фрустрација што, чини се, произлази из чињенице да су, у тренутку писања, Бласимова сећања још увек била тескобна и лишена дистанце, те недовољно зрела да постану грађа његовог књижевног стваралаштва. Иако понекад аматерски срочени, каткад недоречени и усиљени, текстови из ових збирки представљају вид друштвеног или књижевног бунта. Уједно, иза редова ових жанровски и формално аморфних текстова назире се семе из којег ће се развити изванредно приповедачко умеће, мада не и надарен песник, премда су поједини састави или њихови делови саздани од импресивних песничких слика, продорних и оштрих реченица.

Претходно описаном учинку 2018. године придружен је роман упечатљивог наслова - Allāh 99. Његов поднаслов, Imaylāt mutarğim Imīl Sìorān (Мејлови ӥревоgиоца Емила Сиорана), представља омаж његовом пријатељу Аднану ал-Мубараку ('Adnān al-Mubārak, 19352017), који је уистину преводио дела песимистичног румунског филозофа Емила Сиорана (1911-1995), чија је мрачна визија човечанства компатибилна с Бласимовом. Наиме, Бласим кроз читаво досадашње стваралаштво, као и Сиоран, задржава нихилистичку перспективу, односно уверење да је човек проклето створење које безнадежно тумара светом, осуђено на реалност тела - на тај рањиви и измучени оклоп, проводник менталног бола. Сродност Бласимове поетике и Сиоранове филозофије огледа се и у лежерном светогрђу и неспутаном препуштању еротичном, као противтежи смрти и самоуништења. Осим Сиоранових, у Бласимовим делима провејавају поетички назори Борхеса, Бергмана, Кјеркегора, Кафке, Буковског, Милера и Бодлера - свих оних „који су преферирали сопствени пакао над бесмртним рајем“ (Balāsim 2018: 148).

У оквиру наредних поднаслова издвојено је неколико иманентних поетичких стубова досадашњег стваралаштва Хасана Бласима, који дају оријентир у развоју књижевног пута писца, у понечему сродног осталим прозаистима из Ирака, с којима учествује у обликовању препознатљиве савремене ирачке књижевности. 


\section{3. Књижевношћу против књижевности: Бласимова метафикција}

Сва досадашња дела Хасана Бласима прожета су аутобиографским коментарима и метафикцијским алузијама. То је у духу постмодерне књижевности у оквиру које се често у фокус поставља промишљање структуре и смисла властитог приповедања. Бласим описује процес писања, расправља о формалним, жанровским и стилским могућностима своје поезије и прозе, о сврсисходности и улози књижевне речи у животу књижевника, повремено се осврћући и на питања у вези с развојем модерне ирачке, односно арапске књижевности. Ова врста полемике одвија се у форми монолога или дијалога, при чему у потоњем случају писац саговорника налази међу ауторима из света књижевности или међу личностима из њихових фикционалних светова.

Кад расправља о поезији, јасно је да Бласим алудира на статус касиде у арапској књижевној традицији, што је очекивано место преиспитивања, имајући у виду њену улогу од самог зачећа арапског идентитета. Критика касиде као „окоштале“ књижевне

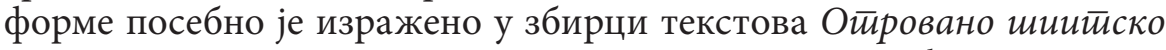
geте e, у којој промишља њену сврсисходност, најчешће уз подсмех према тој „узвишеној, лепој, дубокој, оштрој, једноставној, мудрој, трансценденталној, окађеној, извајаној, младалачкој, светој поезији" (Balāsim 2016a: 20). Однос према касиди каткад је натопљен срџбом и тугом јер је писац доживљава као својеврсно песничко самоубиство (Balāsim 2016a: 50), али и исказује жељу да му се посрећи да напише „празну песму, без њеног величанственог костура“ (Balāsim 2016a: 101).

Ипак, критика касиде не односи се само на њену превазиђену форму и језик који кипти од прашњавих речи, ускладиштених у класичним речницима ${ }^{5}$ - манир који се код појединих песника и данас задржао. Бласимова брига тиче се састављача и реципијената који класицистички начин обликовања свести и идентитета одржавају у животу. Писање, а затим и читање и уживање у касидама доживљава као „доливање уља на ватру“ (Balāsim 2016a: 49), а саму касиду као калуп у који се улије много а да „ипак ништа у њему не остаје“ јер касида је, наставља Бласим, „ходник духова времена“ (Balāsim 2016a: 85).

Бласимова побуна против уживања у клишираној касиди умногоме подсећа на бунт туниског песника ал-Шабија (Abū al-Qāsim

5 Критикујући поетски и прозни израз у арапској књижевности, Бласим се често зауставља код опсежних речника арапског језика, који чине да писање код неких аутора „наликује копању гроба у потрази за речима“, због чега и сама реч писање „има укус пепела и смрти“ (Balāsim 2018: 8). Слични искази учестали су и у другим саставима (нпр. Balāsim 2016a: 110, 112). 
al-Šābī, 1909-1934), који је 1929. године у предавању Al-hayāl al-šír 'ind al-'Arab (Песничка имаїчнација кog Apaӣa) указао на претерану кићеност и празнословље класичних касида, замрзнутих у минулим временима (al-Šābī 2013: 67, 77, 81). Дато уверење, које су у првим деценијама XX века испољили и романтичари махцера (емиграције), појављивало се и касније, у побуњеничким поетикама песника реализма, симболиза и модернизма. Бласимове тврдње указују да су такве теме још увек живе у расправама о даљем усмерењу арапске књижевности.

Кад размишља о прозном стваралаштву, тежиште Бласимове полемике је на питању смисла порива за писање књижевног дела. У таквим приликама Бласим наглашава да не жели да пише ради историјске лекције, поуке, забаве или било ког „несрећног“ књижевног циља, већ да у писању пронађе смирај (Balāsim 2016а: 99). Његова реч постаје „метак испаљен у ваздух“ (Balāsim 2016a: 101), што је метафора којом Бласим као да признаје пораз свог књижевног ангажовања, сводећи га на нечујни крик. Писање постаје средство у терапији, „чаробни анестетик и магични лек“ (Balāsim 2018: 257), којим вида ране проживљене суровости постојања, тако што „избацује отровног црва из срца“ (Balāsim 2019: 51-52). Реч је, дакле, о прихватању стваралачке неминовности, али и њене немоћи да хуманизује и оплемени свет - мисија у којој се књижевност, сматра он, показала готово пораженом (Balāsim 2018: 232-233).

Осим што трага за одговором зашйо писац пише, Бласим пред читаоцем огољава стваралачки процес и показује како писац пише. У збиркама прича је фокус каткад на писцу, читању или стваралачком процесу, али је у питању само „привидно теоретисање о писању“ (Лештарић 2016: 138). У ранијим текстовима, разоткривање стваралачког процеса тече директније, посебно у појединим саставима из

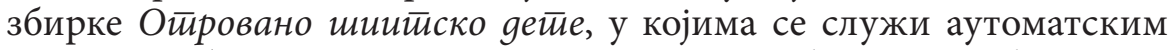
писањем, због чега његов начин писања подсећа на рану фазу надреализма.

Бласим ни у коначној верзији дела не скрива његов сиров нацрт у настајању, што је посебно изражено у роману Алах 99, где је на самом почетку дат план његовог састављања. Бласим у форми исповести говори о инспирацији (извештај о масовној гробници у Ираку), грађи делова романа (животне приче Ирачана које планира да прикупи), о хаотичној структури романа (спонтано, а без епилога), па чак и о новчаном прилогу који му је омогућио да сакупља грађу за роман. Такав поступак указује на тежњу да напише прозно дело у потпутној супротности с традиционалним поимањем форме романа, исто као што је то покушао да учини и у случају поезије.

Осим што се на предочен начин служи постмодернистичком техником огољавања стваралачког процеса, Бласим је склон симу- 
лацији личне исповести, често се представљајући као (непопуларни и цензурисани) писац Хасан (Бласим). Штавише, у роману Алах 99, читалац је дезоријентисан кад је у питању перспектива приповедања, будући да сам приповедач брише границу између аутора и наратора, уверавајући читаоца да је то једна, недељива перспектива (Balāsim 2018: 292). Ипак, већим делом, и у другим причама, Бласим даје глас сваком човеку, без обзира на списатељски таленат, и укида смисао „професионалног“ писца, чак га и обесмишљвајући (нпр. Balāsim 2019: 39-45). У том смислу, неретко оставља утисак пуког преносиоца прича оних који нису кадри да се лате пера, због чега се у његовим делима приповеда некад и из перспективе пса, утваре и духова, па и саме смрти јер, како истиче у поменутом роману, „мртви још увек имају право на иронију и приповедање“ (Balāsim 2018: 15).

\section{4. „Међу јавом и мед сном“: Бласимова фикција}

Прича Алија ел Басравија све време ме је изазивала да о њој пишем, упркос томе што је била мрачна и бременита тугом, с покојим клишеом из кинематографија трећег света која настоји да искамчи нешто сентимента од гледалаца са Запада. Ипак, она ми је у много наврата потврђивала поетички карактер људског лика, скривеног попут драгуља испод милиона тона смећа овог баналног живота. Можда зато што сам песник, и што живим као избеглица на једном оваквом месту, у штали за говеда, имам тврдо срце, или, можда, имам мозак који није лишен мудрости потребне за бављење смешним будалаштинама. Мозак што настоји да, оскудним избором речи, отклони свој гнев и, истовремено, страсно интересовање за суштину људског ужаса. (Бласим 20156: 42-43)

Обухватан поглед на досадашње Бласимово књижевно деловање указује на два главна извора надахнућа. О првом је претходно било речи - промишљање процеса и сврсисходности стваралачког чина, док је други извор надахнућа судбина ирачког народа у новијем следу историјских догађаја. Бласимова популарност је, за сада, заснована на обради потоње теме, онако како је то уобличено у причама две збирке, Луgак са Трїа слобоgе и Ирачки Хрисйос, којима је обухваћено укупно 25 прича.

Иако се фикционални свет Хасана Бласима развијао у Ираку, отелотворен је у Финској, у којој је задржао своју културолошку тачку гледишта. На први поглед, реч је о причама локалног карактера, односно процесуирању тренутака непосредно пре и након ратног разарања у Ираку, али и о суочавању с агресијом и тиранијом уопштено. То је илустровано окрутним духовним и/или физичким скончањем ирачких грађана, неких услед рата, а других током миграције или у туђини. 
Међутим, треба нагласити да се Бласим не бави ратном хроником и деловањем лажних миротвораца у региону. У фокусу је појединац као жртва контекста или сведок немилосрдног окружења. Кад хронотоп обухвата Ирак у постсадамовској етапи, тај контекст чине деловања екстремистичких група, посебно бомбаша самоубица, затим нетрпељивост између Курда и Ирачана, антагонизам сунита и шиита и остала проблематична интерна чворишта.

Немилосрдан шири контекст подразумева тему миграције, а напослетку и неприлагођеност у туђини, што је уобичајена зауставна тачка и код осталих савремених ирачких писаца, али је и свеприсутна тема у модерној арапској књижевности. Ирачки писци литерарно процесуирају вишегодишње покушаје избављења из вишег круга пакла ради преласка у нижи, бег од смрти који се неретко завршава управо смрћу. Тако се и Бласим често враћа на сурова правила миграционе руте и начин на који кријумчари превозе, како каже, „људску стоку с Истока на фарме Запада“" (Бласим 20156: 23). ${ }^{6}$

Туђина као оптимистички исход избеглих с ратних подручја приказана је у Бласимовом приповедању као циљ на коме време не лечи ране. „Избављени“ постају заточеници свог идентитета, прошлости и носталгије, што прожима велики број прича, а једна од познатијих, прерађена и кроз позоришни комад, јесте прича о Карлосу Фуентесу - „Кошмари Карлоса Фуентеса” (Бласим 20156: 48-56). Поред ове приче, сличан утисак оставља и прича „Тај злослутни осмех” (Бласим 20156: 57-66) и бројне епизоде у роману Алах 99, на пример, епизода 99 Швеђана, чији ликови илуструју проклетство привидног избављења (Balāsim 2018: 149-160).

Слике ужаса које избијају са страница Бласимових дела никад нису биле тако згуснуте у арапској књижевности, иако су у оквиру појединих жанрова, изразито у adab al-suğūn (затворска књижевност), осликани свирепи призори мучења. Међутим, такви су се призори у затворској књижевности, као и у adab al-harb (ратној књижевности) и adab al-muqāwama (књижевности отпора), појављивали спорадично, најчешће у тренуцима кулминације, а не као константа, и то уз „успорене“ и детаљније описе, који се протежу на неколико страница. Насупрот томе, у Бласимовом приповедању као да у палети репресалија нема времена за детаље јер чин духовног и/или физичког скончавања долази брзо и ненајављено. Каткад је живот нешто успутно, описан штурим реченицама, само ступањ пређеног пута, увод у живот мртвих тела и живот оних који тај призор носе у себи.

Штавише, у Бласимовим делима живот и смрт су једно. Некад наизглед преживели сведок заправо је обезглављени, осакаћени леш који посматра котрљање своје одрубљене главе или разасуте остатке

6 Поред прича као што су „Камион за Берлин“ (Бласим 20156: 22-29) и „Алијев кофер“ (Бласим 20156: 40-47), Бласим о теми миграције говори у више наврата на страницама романа Алах 99 (Balāsim 2018: 116-122, 172 итд.). 
свог тела. Стога се може рећи да је наслов збирке сабраних прича, Изложба лешева, прикладно одабран јер предочава суштину његове готичке фикције. Прича истоименог наслова у тој збирци (Balāsim 2015a: 69-74), својим готово непојмљивим садржајем - уметничко излагање лешева насумично одабраних цивила - указује на врхунац зверстава којима је човек склон.

Обузет утиском рђавог уређења света и безвредности појединца на његовом „тржишту“, Бласим припада савременој генерацији писаца који се ослањају на постмодернистичке књижевне поступке. Разореност духовног и материјалног уточишта он преноси у хаотичну, нелинеарну прозну нарацију, обједињујући у једној приповедачкој целини различите књижевне форме. То је посебно изражено у колажном роману Алах 99, састављеном од ритмичне смене фрагмената, које чине писма преводиоца и нараторово бележење туђих исповести (краће приче), на моменте испресецаним интертекстуалним и аутобиографским дигресијама. У таквом устројству романа, свака од тих епизода чини се коначним одредиштем, због чега не постоји крај романа у класичном смислу речи већ само његово трајање и привид кретања ка кулминацији и расплету.

У погледу стила, уочљива је разлика између ранијих састава у духу надреалистичког, деаутоматизованог уобличавања мисли, и стила у причама из збирки у којима доминира „сценско“ („објективно“) приповедање у коме су неразлучиво измешани стварност и фантазија. Иако потоња фаза подсећа на магични реализам, термин који приближније карактерише Бласимово укупно стваралаштво јесте кошмарни реализам, саздан од готских елемената који су свеприсутни у његовој ужасом надахнутој књижевности. Такво је усмерење присутно и код других савремених ирачких прозаиста, међу којима су Луај Хамза Абас (Lu’ay Hamza 'Abbās), Синан Антун (Sinān Anțūn) и Ахмед ал-Садави (Aḥmad al-Sa'dāwī). ${ }^{7}$

\footnotetext{
7 Од поменутих ирачких писаца, доступно је по једно преведено дело двојице потоњих. Недавно је роман Синана Антуна Yā Maryam (2012) превео Српко Лештарић с арапског на српски језик, насловивши га Баїgаgско йричешће (Београд: Лагуна, 2020). Роман Ахмеда ал-Садавија Frankaštāyn fī Ba $\dot{g} d \bar{a} d$ (2013) такође је доступан на српском језику од 2019. године (Франкеншйајн у Баїgagy, Београд: Лагуна), премда у посредном преводу Татјане Милосављевић с енглеског језика. Оба романа су ушла у ужи избор Међународне награде за арапски роман, познатије као „арапски Букер” - једне од најпрестижнијих књижевних награда које се последњих десетак година додељују у арапском свету. Баїgаgско йричешће пласирао се 2013. године међу шест најбољих романа, док је Франкеншйајн у Баїgagy био првопласирани роман 2014. године.
} 


\section{5. Прекорачења у изразу и теми: Бласим новим против старог}

Укротићу своје речи. Нећу се ни изблиза ни издалека приближавати Богу, а ни сексу. Оканићу се тога! Писаћу приказе за пристојне филмове и позоришне комаде, или ћу писати ентузијастичне чланке које финансирају политичари, секте или неко племе. Можда ћу писати и о кувању масних арапских специјалитета. Осмислићу дуге арапске серије о мукама платонске љубави. Писаћу девичанским арапским језиком о невиним темама не бих ли ушао у рај. Тамо бих вечно живео го голцат и даноноћно општио с хуријама, јео, пио и живео за бадава. (Balāsim 2018: 251)

Модерна арапска књижевност обично се посматра са становишта друштвене ангажованости, а писци се притом схватају као гласноговорници грађана и хроничари друштвених збивања. С обзиром на вишедеценијску строгу цензуру, алегорија и историјске паралеле, односно метафоре у етимолошком значењу те речи, устаљена су уточишта друштвено ангажованог писца, код смелијих не и једина. Потоњи су склони прекорачењима у погледу искрености у изразу и теми, од начина на који се схвата и употребљава језик, до обраде табу тема, а то су религија, политика и секс. Све су то теме којих се већ неколико деценија, и по цену слободе, поједини писци не лишавају, иако су оне и данас подложне експлицитној и имплицитној цензури на различите начине, онако како се то чини у тоталитарним режимима.

Управо у таквим прекорачењима, избегавајући метафоричку обраду стварности, Бласим настоји да остави траг. У његовом досадашњем књижевном стваралаштву присутно је експлицитно извргавање руглу сакралног наслеђа и задирање у световну интиму. Иако није једини арапски писац који се ноншалантно и неспутано односи према језику и табу темама, Бласим их поставља у средиште свог књижевног деловања.

Најбезазленије у низу прекорачења код Бласима јесте употреба ирачког дијалекта у књижевном дијалогу, понекад и у нарацији, на штету стандардног арапског. После читавог века расправљања, дати поступак може се сматрати извојеваном победом у арапској приповедној књижевности. Но, важно је истаћи да се одабир језичке варијанте код Бласима не темељи само на питању веродостојности. Он „негује“ негативан однос према сакралном статусу стандардног арапског, сматрајући га „духовним и физичким затвореником“ (Balāsim 2018: 263). Исто становиште се у његовим делима, али и у интервјуима, више пута јасно истиче, где се понавља уверење да „већ стотинама година људи нису проговорили на стандардном арапском јер то није језик њихових емоција, брига и радости“, проглашавајући га мртвим језиком, немоћним да изрази живот људи 
и њихове мисли (Balāsim 2018: 263). Бласим верује да стандардни арапски оптерећује књижевни израз јер му даје ноту претеривања, романтике и формалног перфекционизма, што је несувисло за средину коју раздиру насиље, незнање и неправда (Balāsim 2018: 263; сл. Balāsim 2016a: 113). Додуше, ни предочени ставови не представљају преседан у промишљању језика арапске књижевности, али указује на његову дугорочну актуелност.

Друга важна напомена у вези с језиком у Бласимовим делима јесте несметано служење опсценим речима, што није на нивоу инцидента већ заузима важан део у приповедању, а понекад је само себи сврха. Опсцене речи у вези с људским телом и табуизираним сексуалним чином појављују се у обе језичке варијанте, на стандардном арапском и на дијалекту. Ставивши недозвољене речи у јавни простор, Бласим је настојао да разори бедеме канонске књижевности на арапском језику, чија је одлика вековима била уздржаност од преласка преко прага пристојности. Изразита вулгарност у његовим делима каткад прелази границу доброг укуса, и један је од повода што му арапске издавачке куће цензуришу дела тим пре што је прати сексистички приказ жене, што је такође несвакидашње за канонску књижевност.

Наиме, Бласим често у књижевни простор „сервира“ стереотипне слике исииочюачке и зайаgне жене, сводећи их на сексуалне објекте, било да то приказује као ствар избора, што приписује жени са Запада, или кроз неминовност таквог статуса у односу на мушке протагонисте, чему сведочи у случају жене с Истока. У приповедачким епизодама у којима су жене сведене на објекте, опсцене речи доприносе дочаравању порнографских сцена, каткад доведених до одвратности, као да писац жели да изазове гађење и згражавање над позицијом жене у савременом свету. Из тих наратива изузете су представе о ирачкој мајиц - трпељивој, тугаљивој и злостављаној жени у црној хаљини, која ламентира над својом судбином у скривеним угловима куће. Најпластичнији приказ у том смислу дат је у причи „Алијев кофер”, где се каже да „ништа није лакше него рећи да бог не постоји кад се упозна само један дан у животу ирачке мајке” (Бласим 20156: 43). На исту страну, пун саосећања и болећивости, Бласим ставља geвојке йре йунолейсйва - тугу својих мајки, тела без слободе и могућности, које скончавају као ратни плен. То илуструје једна од прича у збирци Ирачки Христиос, насловљена „Сунце и рај”, у којој преплашена мајка штити своју петнаестогодишњу ћерку од „аветних” бораца који силују жене, и то тако што је тера да се до изнемоглости и опекотина излаже сунцу, у нади да ће јој „оставити кћер на миру ако јој тен буде попут препеченог јечменог хлеба“ (Бласим 2016б: 39).

Бласфемични искази су такође трн у оку арапских цензора јер представљају још једну константу у Бласимовим делима. Он негира постојање Бога, или га љутито извргава руглу и поругама јер 
је Земљу, сматра он, учинио „својим личним клозетом“ (Balāsim 2019: 15). Исти третман „уживају“ пророци и свете књиге. Тако, на пример, у једној причи из књиге Човек-речник, Бласим поставља у центар пажње садржај Курана и контрадикторну природу његових поштоваоца, указујући на то да Књигу подједнако „грле“ и џелат и жртва, и диктатор и подјармљени, и убица и сведок - и закључује оценом да је Куран „књига у којој се Бог не стиди да наведе пример“ (Balāsim 2019: 58).

Светогрђе доводи Бласима и до мноштва других неприхватљивих исказа за исламске вернике, па тако у роману Алах 99, опусујући своју мајку, каже: „Она је неписмена као и наш пророк, аутор Кyрана“, алудирајући на посланика Мухамеда (Balāsim 2018: 179). И сам наслов овог романа носи бремениту симболику. У исламској традицији 99 Алахових лепих имена (Asmā' Allāh al-ḥusnā) представљају његова позитивна својства - Милостиви, Благи, Племенити, Заштитник итд. - чије набрајање утире пут ка рају. Међутим, 99 имена у контексту Бласимових дела представља иронију јер их оповргава само овоземаљско устројство или, како каже у једној причи, обраћајући Му се директно: „Поседујеш 99 имена, а ниједно не можеш да докажеш“ (Balāsim 2016a: 40). Таквим бласфемичним иступањима Бласим је изашао на један од најосетљивијих терена не само за арапску књижевност већ за свеколики исламски светоназор.

\section{6. Закључак}

Иако нихилиста и неповерљив према утицају фикционалног на реални свет, Бласим је књижевним деловањем постао препознатљиви грађански активиста и гласноговорник ирачког народа, врсни књижевник и хуманиста. То је показао окушавши се у различитим књижевним формама, уз видан отпор према ограничењима у погледу језика, стила и садржаја. Додуше, Бласимова репутација „можда најбољег живог арапског писца“ ослања се првенствено на збирке прича Луgак са Трїа слобоgе и Ирачки Христиос; остала његова дела не заслужују у целини тако високу оцену. Поетски састави у збир-

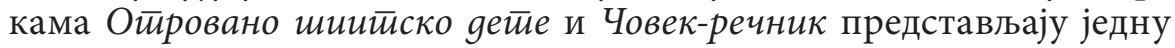
врсту експеримента ради самог експеримента, премда су, истовремено, расадник Бласимових идеја и основ његовог бунтовничког сензибилитета. Роман Алах 99 уследио је као сума пређашњих метафикцијских промишљања и изверзираних приповедачких епизода, али дело као целина пати од сижејне некохерентности, а уз то и приметне усиљености језика и стила.

Ипак, укупно узевши, свако Бласимово књижевно остварење представља својеврсно кошмарно сведочанство из ирачког Хада и реквијем за његове жртве, које буди емпатију и позива на одго- 
ворност. Уз метафикцијски и аутобиографски печат, овај писац својим стваралаштвом предочава слику материјалног и духовног страдања једне нације, њен неизвесни територијални опстанак и обзнањује ужас индивидуе која под притиском унутрашњих сукоба и спољашњег неоколонијалног мешетарења живи у константном страху за голи живот. Пионирско место оваквих преокупација заправо припада палестинској књижевности, посебно од седамдесетих година XX века, којој су се у том смислу убрзо придружиле алжирска, потом и ирачка књижевност, а у том кругу може се рачунати и на новија дела сиријских писаца. Књижевности ова четири народа, чији писци на моменте емитују катаклизмична осећања као подразумеване пратиоце свакодневног живота, не говоре само о локалним проблемима, којима сами писци, као и грађани датих држава не назиру краја већ на један удаљен, за нас „удобнији“ начин, дају увид у еволуцију света у којем живимо - цивилизованост која почиње речју демократија, а завршава се геноцидом.

\section{ИЗВОРИ}

Бласим, Хасан. Луgак са Трїа слобоge. Превео Српко Лештарић. Београд: Геопоетика. 20156.

Бласим, Хасан. Ирачки Христиос. Превео Српко Лештарић. Београд: Геопоетика. 20166.

Balāsim, Ḥasan. Máraḍ al-ğitaț. Milano: Manšūrāt al-Mutawassiț. 2015a.

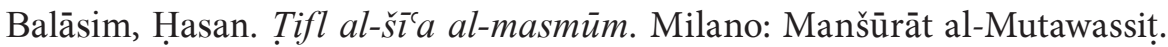
2016a.

Balāsim, Hasan. Allah 99 - Imaylāt mutarğim Imìl Sīorān. Milano: Manšūrāt al-Mutawassit. 2018.

Balāsim, Ḥasan. Al-rağul al-qāmūs. Bayrūt: al-Ráfidayn. 2019.

\section{ЛИТЕРАТУРА}

Јасин-Касаб 2010: Yassin-Kassab, Robin. „Beirut 39: New Writing from the Arab World, edited by Samuel Shimon". https://www.theguardian.com/ books/2010/jun/12/beirut-new-writing-arab-world. 12. 6. 2010. [приступљено 14. 12. 2020]

Камера д’Афлито, Изабела. Савремена арайска книжевности. Превеле Ивана Симић и Марија Ђојбашић. Београд: Завод за уџбенике. 2012.

Лештарић, Српко. „Необуздани љубавник кратке приче“. Абдусетар Насир. Најсрећнији човек на светй. Превео Српко Лештарић. Београд: Геопоетика. 2004. 277-319. 
Лештарић, Српко. „Западно-источни диван 21. века и поруке Истока”. Хасан Бласим. Луgак са Тріа слобоge. Превео Српко Лештарић. Београд: Геопоетика. 2015. 149-165.

Лештарић, Српко. „Поговор - Још о источно-западним сукобима, везама и диванима". Хасан Бласим. Ирачки Хрисииос. Превео Српко Лештарић. Београд: Геопоетика. 2016. 131-142.

Танасковић, Дарко. „Проза Фуада Текерлија”. Фуад ат-Такарли. Друі̄o лище. Превеле Јасна Шамић и Зихнија Имамовић. Загреб: Младост. 1980. 149-156.

'Alwān, 'Alī 'Abbās. Tatawwur al-šì'r al-'arabì al-hadīt fĩ al-'Trāq. Bag̉dād: Wizārat al-i`lām. 1975.

Bahoora, Haytham. „Iraq”. The Oxford Handbook of Arab Novelistic Traditions. Edited by Wail S. Hassan. Oxford University Press. 2017. 247-264.

Al-Ğayyūsī, Salmā al-Hadrāà. Al-ittiǧāhāt wa al-harakāt fī al-šíir al-'arabī al-ḥadīt. Bayrūt: Markaz Dirāsāt al-waḥda al-'arabiyya. 2007.

Al-Šābī, Abū al-Qāsim. Al-hayāl al-šìirì 'ind al-Arab. Al-Qāhira: Hindāwī. 2013.

Meysun Gharaibeh Simonović

Hassan Blasim: A Requiem for Iraq, a Requiem for Literature

Summary

The paper discusses the work as well as immanent poetic views of the contemporary Iraqi prose writer Hassan Blasim. His literary works thus far include two collections of poetic and prose compositions that were written over a period of time, The Shia's Poisoned Child (2016) and Dictionary Man (2019); two collections of stories, The Madman of Freedom Square (2009) and The Iraqi Christ (2013); and finally the novel God 99 - Emails of the Emil Cioran Translator (2018). Blasim's gift for writing, expressed in prose miniatures found in these collections, earned him the status of "perhaps the greatest living Arab author", and the 2014 Independent Foreign Fiction Prize, as well as being short-listed for a number of other important literary awards.

Each of Blasim's literary works is a kind of nightmarish testimony coming from the Iraqi Hades and a requiem for its victims, causing empathy and calling for responsibility. Through his work, the author revises the image of the material and spiritual downfall of a nation, its uncertain territorial survival and reveals to us the horror of an individual living in constant fear for his or her life, pressured both by internal conflicts and external neocolonial wheeling and dealing. Blasim performs an exhumation of the Iraqi national being, an autopsy of the body and a biopsy of the soul, collecting their fragmented lives and burying them in his fiction. He does this in a narratively skillful, stylistically diverse manner, ranging from surrealist 
contemplation to nightmarish realism, prone to illicit excesses in expression and theme, contrary to canonical Arabic literature. It is through these transgressions that Blasim tries to leave a mark, indulging in explicit mockery of the sacral heritage and intrusion into secular intimacy. Even though he is not the only Arab writer who has an unfettered and nonchalant way of dealing with language and taboo topics, Blasim places them at the center of his literary works.

In addition to analysing the world of Blasim's fiction, the paper also points to metafictional threads that permeate a large number of Blasim's works or are in their focus, especially in terms of the creative impulse and the meaning of writing Arabic poetry and prose in particular, as well as literature in general. This is in the spirit of postmodern literature, in which the focus is often placed on rethinking the structure and meaning of one's own narration. Therefore, Blasim dwells on the process of creation (formalistic, stylistic and genre possibilities of storytelling), on the purposefulness and role of the literary in the life of a writer, referring back to some of these issues in the historical development of Arabic literature, especially its poetic heritage. This discussion takes place in the form of a monologue or dialogue, where, in the latter case, the author's interlocutors are other writers from around the world, or characters found in their works.

The subheadings used in the paper are named after the main pillars of Blasim's poetics. These landmarks can be used to trace the creative path of this author, who after all shares some features with other prose writers from Iraq, and with whom he participates in shaping contemporary Iraqi literature.

Keywords: contemporary Iraqi literature, contemporary Iraqi prose, Hassan Blasim, metafiction, fiction, nightmare realism

Примљен: 30. 3. 2020.

Прихваћен: 15. 10. 2020. 